\title{
Comparative Study of Paradigm on Character Education Perspective by Paulo Freire and Ki Hajar Dewantara
}

\author{
Shafira Arifah Putri \\ Law Islamic Family Department, Faculty of Syariah, IAIN Surakarta. \\ J1. Pandawa Dusun IV Pucangan Sukoharjo, 57168, Indonesia. Tel. (0271) 781516, Fax. (0271) 782744 \\ Email: shafiraarifahputri88@gmail.com.
}

\begin{abstract}
Nowadays, when science and technology continue to grow rapidly, character education precisely more gets eroded. It shows, there has been morals degradation in the middle global mainstreaming. The authors using of character education prespective by two phenomenal figures to be discussed, Paulo Freire and Ki Hajar Dewantara. Both give a more attention to the paradigm education that is able to answer new challenges. Freire thought to give a solution by is leaving magical and naive education, switch to concept critical education that freed humans leads to a new colour in the proggressive change. Whereas, thought Dewantara to show a concept "trilogi" that is how the role family, school, and public able to formation movers character and children mentality along through system "among" based on Ing Ngarsa Sang Tuladha, Ing Madya Karsa, and Tut Wuri Handayani. The method that is used in this research analytic comparative method, that is by to analyze in a looking for sides similarity and difference of thought. The purpose of this research is to describe character students towards the future better.
\end{abstract}

Keywords: The Formulation Paradigm, Perspective, Character Education.

\section{INTRODUCTION}

Alvin Tofler a futurologist use that term "Future Shock" for illustrate now situation that is "a condition shake it individual psychology because too much faced change in too short of time". (Alvin Tofler, 1971). The application full-day school rated hamper development the students to think democratic and civilized, they just be created as "robot" which follow rigid the rules and curriculum. The school only attach importance pursue theory and overrides aspect psychology of children. Depolitation tendency to show formal education a fragile, when the student preoccupied with school activity so that, they are not got a chance self-developed to build consciousness and critical behave. With more opened technology and information system as authorities which susceptible, by supervision parent and school to various media network not able will ensure directing children in the stay positive environment. The problem above answer that we very need education character recovery to upgrade think logically. Well in advance, character pedagogic already thought even first by two figure phenomenal, Paulo Freire and Ki Hajar Dewantara an activist education from Brazil and Indonesian education father in which thought put forward by two figure is education as a process that freed humanity from the darkness towards light brightly. Although they from different background, however was found similarity which very relevant, if be linked with today. About urgency education poured out in brilliant ideas by Freire and Dewantara to answer that challenge future through character education with realize human civilization which civilized. The difference not a barrier to aligning them, related with the existence scope their the both. Surely, they that education will save nation from the backwardness.

\section{MATERIALS AND METHODS}

This research using analytic comparative method. The analytic comparative conducted by the authors to search on various written sources which relevan to character education perspective by Paulo Freire and Ki Hajar Dewantara. To analyze similarity and difference between of them, author is using method comparative from two thought in the problem same. Paulo Freire thought to construction that critical and transformation education, meanwhile Ki Hajar Dewantara applicated multiculturalism education equitable. Combine collected data from a several books, analyze, and write.

\section{RESULT AND DISCUSSION}

\section{Problem Solving of Character Education}

To bridging reception aspect cognitive on children then be required aspect psychology to self actualize for around environment which will open insight and skill they have. Method learning based on inquiry, search, problem-solving, and the like very precise to apply in the current era. (Edi Subkhan, 2017). Rule out culture and exemplary as a hidden curriculum easy found in school, moreover to upgrade quality human resources which more day more undeniable. Knowledge and skill 
continue be sharpened but character eroded more by change time. Responded to the problem, that education aim that to glorify and distinguish human with living things the other. Squirm it's technology to show more opened and be easy productivity in life, however, there is one thing which not could be formed by technology that is moral. Character education need harmonized with hardness enactment education cognitive. Next steps, that is able to answer that problem regardless of demands student should dominate scientific knowledge because reality which we facing now education distance away individuals inside it from humanity. (Nurani Soyomukti, 2008). These emphasis to purpose birth new inspiration which bring we generation to think globally, so that with whole could to define the relationship between humans.

\section{Paulo Freire of Biography}

Paulo Freire was born at the date of 19 September 1921 in Recife, Northeast Brazil. He educated to be a lawyer at the University of Recife. He books which title "Pedagogy of the Oppressed" much influenced by Frantz Fanon through book with a title "The Wretched of The Earth". Begin activities social in Pernambuco with a program education to poor society and laborers. Himself careers to much experience steep road consequence the influence of a political coup until finally he appointed as Secretary of Education. Under the direction, held program education transformative as revamping education system, the participation of public, and he declares that education have strong relation with politics. Freire too known as an intellectual which able to actualize theory into the practice literacy cross world. He idea much poured in the book theoretical about critical education. Until now, idea of Paulo Freire still in use by various over the world.

\section{Freire Thought}

Freire determined to eradicate illiterate so that public in it's environment able to understand development social, politics, and economy which leads to system democrate. (William A. Smith, 2008). Freire idea introduces concept education which able to make a public that is ready to evolve. Therefore, he offers critical education with leave magical and naive education which able implemented in the problem world of pedagogy at now that is disappearance paradigm character education. Magic education is when student able self adapted with reality which exists and always subject to what has been set or ordered. Different from naive education, consciously student understand about social conditions it's environment but act apathetic. Every student indirectly have realized that they just are enslaved by theory which is monotonous. Even so, because education reconstruction which was built set each act behaviour student, they not able left alone free to choose education appropriate with their ability. In the world of economics, the student just becomes sheer consumer, instead of becomes producer. Doesn't mean, school limited every student's rights, but syllabus the applied become a shield, so that they already familiar with the regulatory applicated. This here, the summit point Freire need to change awareness in scope pedagogy.

Critical education born because effect above strive to change the order on frame towards social transformation. This concept is ideal to is trying against existing policies, however was built in critical awareness. More students play an active role at each activity the learning both outside and inside the classroom, they able to naturally act corresponding with limits and encouragement from the role facilitator that is family, teacher, and public. They be brave take a risk and active participation through cooperation. The maturity students grow in coaching full of by the facilitator role with to form spirit, motivation, confidence, discipline, and attitude of responsibility in quality and quantity every. See reality developing now, character education princip not which was stated by Freire that is education as practice liberation not only a process transfer or knowledge transmission which is contained in various cultures. That's point, education it's not action to deposit information or fact but is knowing have occurred contradiction between of rhetoric with reality.

\section{Ki Hajar Dewantara of Biography}

Ki Hajar Dewantara was born in Yogyakarta at the date of 2 May 1889. After himself graduate from school STOVIA, he active as a journalist in some newspapers and also started take a part within organization social politics. In 1908, he becomes section propaganda Budi Utomo to principal interests national unity and integrity, not until there he also establishes political parties Indische Partij together with Douwes Dekker, Dr. Cipto Mangkusumo known as "Tiga Serangkai". He inscription "Als Ik Eens Nederlander Was" is causing he has been undergoing punishment disposal the Netherlands. When Dewantara go back to Indonesia, he builds Taman Siswa with reject colonialism education. The effort of Ki Hajar through Taman Siswa it sparks soul spirit nationality people of Indoensia too is studying. After independence era, he officiate as the first Minister of Education, Pedagogy and Culture. On date 26 April 1959 he died and buried in Wijayabrata, Yogyakarta.

\section{Ki Hajar Dewantara Thought}

Ki Hajar Dewantara is offering system "trilogi" which role build up and educated children with by involving the role parents, school, and public. The role of parents as determinant children character, got morals cultivation since the early stage because take a big effect in determining achievement children future goals. As a maker policy "praksis" based on value virtue which attached to behavior human instinct as honesty, courtesy, philanthropy, high work ethic will a produce child quality personality. Conversely, parents negative 
behavior will spread "virus" to children. So that, engender attitude indifferent inside them. Intertwining good comunication between parents and children able to create a behavior considerate grace, so that raise each other understanding to both. Currently, the school very ambition to moulded clever student within reach high score, and to pursue or upgrade the image of schools. The school have broken away from implantation of character education value. The essentially, education has two sense dual that's, the education to reach cognitive aspect and education as shaper student identity. As a shaper, school the role very important through cold hands a teacher in term Java as known as "digugu lan ditiru". This philosophy is teaching be a good teacher is a teacher not which become a ruler but as a mentor with friendliness. On process transfer knowledge teacher not a give such pressure or demand heavy is causing a student stressful and frustrating leads to negative behavior. Therefore, strive for giving motivation and stimulation in a comprehensive. The public as assessor factor and controller children behavior, only have a little the role but on scope is not which the restricted. In this extensive environment, children is indirectly got the appropriate pedagogy or inappropriate make as social beings to undergo life. (Moh. Yamin, 2017). All three roles, according to $\mathrm{Ki}$ Hajar Dewantara if the reflected to character education in the middle recent technology rated very right to apply because providing influence to the world of pedagogy now and tomorrow.

The method "among" related with basic word Mong which a cover Momong, Among, and Ngemong. (Suparto Rahardjo, 2012). Momong in terms Java means it takes care of sincere and full affection be accompanied with prays and hope able to transform children, so that, always located in the way of truth. While among including the process walang wuruk means it teaching about good and bad value accompanied by introduced punishment to example behaviour in this step corresponding with it's nature. Last, Ngemong is process something to educate so child able to be responsible and discipline above the act which has been done. In the attitude able to be attracted a statement that through the role, a teacher, the parents, and the public accommodate the growing children behavior in achieving their dreams. They the task is not just dictate, but to support mindset and child development. The system among is teaching the meaning of independence in world of pedagogy. Education aim that to create the life established mind and character not just to efforts for living just based on knowledge, but is forgetting character education as starting point measuring the scientist. Behavior negative student born education system consequence which is boring, very deviate from system "among". The system among based on the following three things. First, Ing Ngarsa Sung Tuladha (In Front Should Set an Example), Ing Madya Mangun Karsa (In The Middle Should Raise The Spirit), dan Tut Wuri Handayani (Behind Should Give Encouragement). So that, implicit in this case, it is the parents, teacher, and public not only be a role model but also creates the spirit so that pushes so the child can self is empowering for achievements of his life goals. The liberation in education which was initiated by Dewantara is overseeing and restricted, the meaning of giving a reproof and direction when the child takes the amiss road.

\section{Comparative Study of Paulo Freire and Ki Hajar Dewantara Thoughts \\ The Similarity of Freire and Dewantara Thoughts}

Both they are some understand that education will to the purpose of reality the real-life, education is held democratically and not discriminative with upholding human rights. Educational development also not able regardless from political efforts. They also agreed, that education as a way to aware of essence human creation not only to be a clever but the make be a good moral human. Both have also been successful motivate the human to broke away from ignorance and backwardness.

\section{The Difference Between Freire and Dewantara Thingking}

Based on their background, both have area coverage and difference paradigm. Teachings Freire more universal characteristic and the theory taught already adopted by UNESCO. Focused Freire with to construct critical education that is to develop a new life model which is juster.Through education, make student as a social agent aware of them to public structure which is not fair and silent culture leads to create new condition social the humane. Deficiency from this education system is the problem which tends just to answer a conflict or stagnant. Critical education contradict with thought Dewantara. For Freire, critical education is each person entitled to freedom get an education without limited by whatsoever. But, Dewantara argues that freedom is relative through the education method is that "trilogi" and "among".

Refer to is teaching Ki Hajar Dewantara more are nationality, he adduces a lot of ideas regarding Indonesian society untouched by education. Briliant idea Dewantara is that with establishing Taman Siswa not take a foreign culture which will be constructed in system educational order in Indonesia have a foundation national education still used today. If Freire focused on critical education another thing with Dewantara, he develops multicultural be fair education system which is egalitarian and always grow tolerate to the cultural diversity of the community. If each person same equality before the law as well as so too individual who gets the same rights and opportunities in education. This concept of education able to answer challenges in the middle diversity increasingly complex. 


\section{CONCLUSIONS}

Saving the nation from backwardness and also as efforts are seeing technology development which is very fast. A between hard skill with soft kill must balance. Rule out of soft kill judging by as a strategy it is not right. That's why, very needed character education as which ideas by Paulo Freire and Ki Hajar Dewantara that is education that means able to understand the world and ready for changes. The both also accord that education as process bridging learning so that is able to be applied in the reality of social life. The result of research to show the existence of different thought paradigm on character education. Paulo emphasizes more on critical education to change old conditions which oppress with to create new conditions more humanly. Different Ki Hajar emphasizes more about multicultural education equitable, in the middle diversity all people rightfully get education the same and equal without compare degrees.
Urgency other character education, able shore civilized and quality.

\section{REFERENCES}

A, William Smith. 2008. Translated from a Book of the Meaning of Conscientizacao, The Goal of Paulo Freire's Pedagogi by Agung Prihantoro. Pustaka Pelajar, Yogyakarta.

Rahardjo Suparto. 2012. Ki Hajar Dewantara Biografi Singkat 1889-1959. Garasi, Yogyakarta.

Soyomukti Nurani. 2008. Pendidikan Berpersepektif Globalisasi. Ar-Ruzz Media, Yogyakarta.

Subkhan Edi. 2017. Pendidikan Kritis Kritik atas Praksis Neoliberalisasi dan Standardisasi Pendidikan. Ar-Ruzz Media, Yogyakarta.

Tofler Alfin. 1971. Future Shock. Bantam Books, New York.

Yamin, Muh. 2017. Mengugat Pendidikan Indonesia: Belajar dari Paulo Freire dan Ki Hajar Dewantara. Ar-Ruzz Media, Yogyakarta. 